\title{
Edible films and coatings based on mango (var. Ataulfo) by-products to improve gas transfer rate of peach
}

\author{
Cristian Torres-León ${ }^{\mathrm{a}}$, António A. Vicente ${ }^{\mathrm{b}}$, María L. Flores-López ${ }^{\mathrm{b}}$, Romeo Rojas ${ }^{\mathrm{c}}$, \\ Liliana Serna-Cock ${ }^{\mathrm{d}}$, Olga B. Alvarez-Pérez ${ }^{\mathrm{a}}$, Cristóbal N. Aguilar ${ }^{\mathrm{a}, *}$

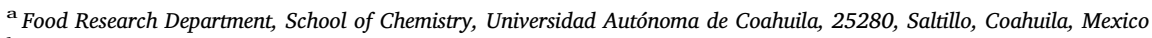 \\ ${ }^{\mathrm{b}}$ CEB - Centre of Biological Engineering, University of Minho, Campus de Gualtar, 4710-057, Braga, Portugal \\ ${ }^{\mathrm{c}}$ Research Center and Development for Food Industries, School of Agronomy, Universidad Autónoma de Nuevo León, 66050, General Escobedo, NL, Mexico \\ ${ }^{\mathrm{d}}$ School of Engineering and Administration, Universidad Nacional de Colombia, Street 32 Chapinero. Palmira, VC, Colombia
}

\section{A R T I C L E I N F O}

\section{Keywords:}

Mangifera indica $L$.

Agroindustrial by-products

Mango seed

Edible coating and films

Fruits

\begin{abstract}
A B S T R A C T
Fruit waste and by-products are economical materials for the development of biodegradable and active packaging. The aims of this study were to develop, characterize and evaluate biodegradable coatings and films by using mango peel and antioxidant extracts of seed kernel. The proximate composition of peel was also determined. Structural, barrier, optical and antioxidant properties were analyzed in the films. Gas transfer rates and the ethylene production in peach were evaluated. Edible films formulated with mango peel showed good barrier properties, with the water vapor permeability varying from $0.88 \times 10^{-10}-1.00 \times 10^{-10} \mathrm{~g} \mathrm{~m}^{-1} \mathrm{~s}^{-1}$ $\mathrm{Pa}^{-1}$. The addition of antioxidant extract does not show a significant effect $(\mathrm{p}>0.05)$ on optical properties. Furthermore, antioxidant activity and polyphenol content increased by $18 \%$ and $60 \%$ respectively. Peach coated with a solution of mango peel (1.09\%), antioxidant extract of mango seed kernel $\left(0.078 \mathrm{~g} \mathrm{~L}^{-1}\right)$ and glycerol (0.33\%) showed $64 \%$ and $29 \%$ less ethylene and $\mathrm{CO}_{2}$ production, respectively, and $39 \%$ less $\mathrm{O}_{2}$ consumption when compared with peaches without coating. The reduction in gas transfer ensures the greater extension of the shelf life of fruit treated. By-products of mango may thus be suitable for the production of low-cost biodegradable and active packaging.
\end{abstract}

\section{Introduction}

Nowadays, short shelf life of fruit and vegetables is one of the biggest trading problems. Although packaging plays a decisive role in the improvement of the shelf life, the high accumulation of plastic packing materials has generated a growing concern in the world, as only $5 \%$ of the production of plastics are recycled (Espitia et al., 2014). In this context, the biodegradable edible coatings or films are an alternative to the replacement of synthetic packaging (Azeredo, Rosa, Souza, \& Waldron, 2014). An edible coating or film is defined as primary packaging made from edible components; in which the layer of edible material may be used in liquid form to directly coat the food or formed as a solid sheet in the form of a film (Galus \& Kadzińska, 2015). Some of their main functions are to protect the produce from mechanical, physical and chemical damages, and also of microbial contamination and the reduction in the transfer of gases (Falguera, Quintero, Jiménez,
Muñoz, \& Ibarz, 2011). Also, bioactive ingredients as antioxidants can be incorporated into the matrix, thus enhancing functional attributes of the formulation (de Moraes, Haas, de Oliveira, \& Hickmann, 2016).

A variety of polymers such as starch (Chiumarelli \& Hubinger, 2014), pectin (Taqui \& Stamatin, 2014), chitosan (Elsabee \& Abdou, 2013), galactomannans (Cerqueira et al., 2011), alginate (Guerreiro, Gago, Faleiro, Miguel, \& Antunes, 2015), proteins (Belyamani, Prochazka, Assezat, \& Debeaufort, 2014), and wax (Ochoa et al., 2011) have been used in the formulation of edible coatings or films. Therefore, the research and characterization of new biopackings based on unconventional sources is a trend (Falguera et al., 2011), highlighting renewable materials that are abundant in Nature (Cazon, Velazquez, Ramírez, \& Vazquez, 2017). In this context, fruit by-products present potential benefits such as the reduction of manufacturing costs, the generation of added value and the enhancement of functional properties (Ayala et al., 2011; Schieber, Stintzing, \& Carle, 2002; Varzakas,

\footnotetext{
* Corresponding author.

E-mail addresses: ctorresleon@uadec.edu.mx (C. Torres-León), avicente@deb.uminho.pt (A.A. Vicente), mlfl.flores@gmail.com (M.L. Flores-López), romeo.rojasmln@uanl.edu.mx (R. Rojas), 1serna@unal.edu.co (L. Serna-Cock), berenice.alvarez.perez@uadec.edu.mx (O.B. Alvarez-Pérez), cristobal.aguilar@uadec.edu.mx (C.N. Aguilar).
} 
Zakynthinos, \& Verpoort, 2016). By-products of mango processing industry are an example of by-products that can be used for the formulation of biodegradable packaging. The peel has a high content of polysaccharides (Serna, García, \& Torres, 2016), while the seeds of mango have high content of bioactive compounds (Abdalla, Darwish, Ayad, \& El-Hamahmy, 2007; Abdullah, Mohammed, \& Abdullah, 2014; Dorta, González, Lobo, Sánchez-Moreno, \& de Ancos, 2014; Ribeiro \& Schieber, 2010), with important antioxidant properties (Torres et al., 2016). One of the most important parameters to consider when evaluating the potential of a biomaterial in the formulation of edible films is their barrier properties (Cazon et al., 2017). Furthermore, the wettability and respiratory rate on a model fruit are of vital importance to determine the feasibility in the application of edible coatings (Cerqueira, Lima, Teixeira, Moreira, \& Vicente, 2009). A fruit model with suitable characteristics to evaluate edible coatings is the peach (Prunus persica), as it has a fast maturation rate once harvested (Guillén et al., 2013). Therefore, the objectives of this work were: (a) to characterize edible films of mango peel added or not with seed extracts in terms of their barrier, optical and antioxidant properties, and (b) to evaluate the application of edible coatings formulated with peel and seed extracts of mango in the respiratory rate, ethylene production and surface properties of fresh peaches.

\section{Materials and methods}

\subsection{Chemicals}

Glycerol, 2,2-diphenyl-1-picrylhydrazyl (DPPH), Folin-Ciocalteu reagent, gallic acid (GA) were purchased from Sigma Chemical Co. (St. Louis, MO, USA.).

\subsection{Mango by-products}

Mangos (Mangifera caesia, cv. 'Ataulfo') were obtained from a local market in Saltillo, Coahuila, Mexico in March 2015. These were selected in commercial ripening stage and caliber number 16 (NOM-188SCFI, 2012). The mangoes were used soon after the purchase, the pulp was manually separated from the peel and seed.

\subsubsection{Obtaining mango peel flour}

In order to obtain the mango peel flour (MPF), mango peel was dried at $60^{\circ} \mathrm{C}$ in an oven (Napco Model 322) for $48 \mathrm{~h}$ and subsequently ground in a mill (Pulvex 100MINI, México).

2.2.1.1. Chemical composition of MPF. The flour was analyzed for its content in ash (A) at $550^{\circ} \mathrm{C}$ for $8 \mathrm{~h}$ crude protein content (CP) was conducted by the Kjeldahl method with a conversion factor of 6.25 , and lipids content (L) (ether extract by the Soxhlet system) as described by the AOAC (AOAC 920.39, 1990). The content of soluble and insoluble fiber was evaluated by the gravimetric enzymatic methods (AOAC 991.43, 1993). Cellulose, hemicellulose and lignin contents were calculated by determining neutral detergent fiber and acid detergent fiber by the method of Van Soest, Robertson, and Lewis (1991). Total carbohydrates $(T c)$ were calculated using the following equation (1):

$T c=100-\% A+\% C P+\% L$

where $T c$ represents the total carbohydrates, $\% A$ represents ash content, $\% C P$ represents crude protein content and $\% L$ lipids content.

\subsubsection{Obtaining extracts of the mango seed kernel}

Antioxidants were extracted from the seed kernel according to the methodology reported by Torres, Rojas, Serna, Belmares, and Aguilar (2017a). Briefly, $1 \mathrm{~g}$ of kernel was homogenized on a vortex tube mixer with $90 \%$ ethanol; the extraction conditions were: kernel weight-tosolvent volume ratio $1: 50(\mathrm{w} / \mathrm{v})$, temperature of $75^{\circ} \mathrm{C}$ and 2 extraction cycles using microwave (MARS 6-USA). The extract was used for its high antioxidant potential (Torres et al., 2017a).

\subsection{Films and coatings preparation}

The filmogenic solution was prepared following the method of Fai et al. (2016), with some modifications. Briefly, MPF was used at a concentration of $1.09 \%\left(\mathrm{w} \mathrm{v}^{-1}\right)$ and glycerol $0.33 \%\left(\mathrm{w} \mathrm{v}^{-1}\right)$, which were chosen based on preliminary tests (data not shown). In order to form the films/coatings, the MPF (particle size $<125 \mu \mathrm{m}$ ) was dissolved in a citrate buffer solution ( $\mathrm{pH} 4.5)$ with constant agitation (Corning pc-220, USA) at $250 \mathrm{rpm}$ for $45 \mathrm{~min}$ at $70^{\circ} \mathrm{C}$ and filtered through polyester cloth meshes. Subsequently, glycerol was added to the solution and kept under constant agitation at $70^{\circ} \mathrm{C}$ and according to the treatment was added or not the antioxidant extract (E). Finally, the temperature was lowered abruptly at $5{ }^{\circ} \mathrm{C}$ using an ice bath. In summary, two emulsion-based edible films and coatings were obtained, $\mathrm{F}$ : containing MPF (1.09\%) and glycerol (0.33\%), and FE: containing MPF (1.09\%), glycerol $(0.33 \%)$ and extract of mango seed $\left(0.078 \mathrm{~g} \mathrm{~L}^{-1}\right)$. The concentration of antioxidant extract was selected according to a previous study of our research group (Torres et al., 2017a), and corresponds to the concentration of extract required to reduce the initial concentration of DPPH radicals by $50 \%\left(I C_{50}: 0.078 \mathrm{~g} \mathrm{~L}^{-1}\right)$.

The film was produced from the formulation $\mathrm{F}$ and $\mathrm{FE}$ by casting technique $(30 \mathrm{~mL})$, which were dispersed in polystyrene plates $(9 \mathrm{~cm})$ and dried at $50{ }^{\circ} \mathrm{C}$ for $16 \mathrm{~h}$. The films were removed manually from the plates (Fig. 1) and stored at $20^{\circ} \mathrm{C}$ in a desiccator at $50 \%$ relative humidity (RH) for at least $24 \mathrm{~h}$. The analysis was performed immediately after.

\subsection{Evaluation of edible films}

\subsubsection{Film thickness}

The film thickness was measured with a digital micrometer (No. 293-561, Mitutoyo, Japan). Five thickness measurements were taken on each testing sample in different points (Razavi \& Zahedi, 2015), and the mean values $(n=6)$ were used to calculate permeability.

\subsubsection{Water vapor permeability (WVP)}

The WVP was performed gravimetrically according to the method ASTM E96-92 (ASTM E96-92; 1990) with some modifications. Films were sealed on the top of a permeation cell containing silica $(0 \% \mathrm{RH}$; $0 \mathrm{~Pa}$ vapor pressure at $20^{\circ} \mathrm{C}$ ), permeation cells were placed in a desiccator at $20^{\circ} \mathrm{C}$ and $100 \% \mathrm{RH}$ (2337 Pa vapor pressure). The cells were weighted at $1 \mathrm{~h}$ intervals for $6 \mathrm{~h}$. Steady-state and uniform water pressure conditions were assumed by keeping the air circulation constant. The WVP $\left(\mathrm{g} \mathrm{m}^{-1} \mathrm{~s}^{-1} \mathrm{~Pa}^{-1}\right)$ of the films was determined by the following Equation (2).

$W V P=\frac{W V T R \times L}{\Delta P}$

where $W V T R\left(\mathrm{~g} \mathrm{~m}^{-2} \mathrm{~s}^{-1}\right)$ is the water vapor transmission rate through the film calculated from the slope of the curve divided by the film area;
A)

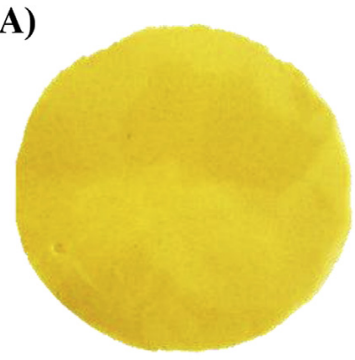

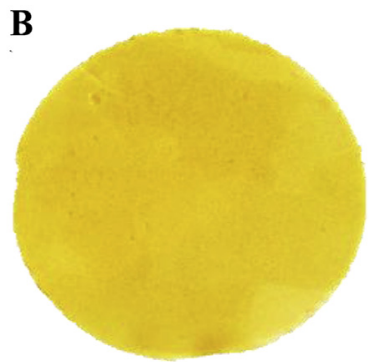

Fig. 1. Edible films based on mango by-products: (A) peel-based film and (B) peel-based film with antioxidants of mango seed kernel. 
$L(\mathrm{~m})$ is the mean film thickness; $\Delta P(\mathrm{~Pa})$ is the partial vapor pressure difference across the two sides of the film.

\subsubsection{Moisture content and water solubility}

Film samples $(1 \mathrm{~cm} \times 7 \mathrm{~cm})$ were first weighed $\left(M_{O}\right)$ and then placed in an oven at $105^{\circ} \mathrm{C}$, during $24 \mathrm{~h}$ until constant weight. After, the films were weighted $\left(M_{1}\right)$ again. Moisture content was determined as the percentage of initial film weight lost during drying and reported on a wet basis with the following equation ( $\mathrm{Li}, \mathrm{Miao}, \mathrm{Wu}, \mathrm{Chen}, \mathrm{\&}$ Zhang, 2014):

Moisture content $=\frac{\left(M_{0}-M_{1}\right)}{M_{0}} \times 100$

The films previously dried at $105^{\circ} \mathrm{C}$ and with reported weight $\left(M_{1}\right)$ were immersed in $50 \mathrm{~mL}$ of distilled water and placed in a shaker water bath at $25^{\circ} \mathrm{C}$. After $10 \mathrm{~min}$, the samples were filtered through polyester cloth meshes, insoluble film was dried to constant weight $\left(M_{2}\right)$ using an oven at $105{ }^{\circ} \mathrm{C}$ to calculate water solubility of the film using the following equation (Cuq, Gontard, Cuq, \& Guilber, 1996):

Water solubility $=\frac{\left(M_{1}-M_{2}\right)}{M_{1}} \times 100$

where $M_{0}, M_{1}$ and $M_{2}$ are the weights of initial, dry matter and insoluble dry matter, respectively. All tests were carried out in triplicate.

\subsubsection{Color, light transmission rate, and film transparency}

The CIE $L^{*} a * b *$ scale was used to determined $L^{*}$ (lightness), $a^{*}$ (redness, greenness) and $b^{*}$ (yellowness, blueness) color parameters, using a 3nh Colorimeter (NR20XE, China). Light transmission rate and film transparency were measured at $600 \mathrm{~nm}$ using UV/visible spectrophotometers (Genesys 20, USA) according to the method reported by Zhang and Han (2006).

Transparency $=\frac{A_{600}}{\text { Thickness }}$ or $-\frac{\log T_{600}}{\text { Thickness }}$

where $A_{600}$ and $T_{600}$ are absorbance and transmittance at $600 \mathrm{~nm}$, respectively.

\subsection{5. $D P P H$ radical scavenging activity}

The reduction of DPPH radical was made following the methodology reported by Molyneux (2004) with some modifications. A solution of DPPH at $60 \mu \mathrm{M}$ was prepared, $193 \mu \mathrm{L}$ of DPPH solution was mixed with $7 \mu \mathrm{L}$ of film solution in each well of a microplate. After $30 \mathrm{~min}$ of reaction under dark conditions, absorbance was measured at $517 \mathrm{~nm}$, using a spectrophotometer microplate reader (Epoch, BioTek Instruments, Inc.; Winooski, VT, USA) controlled with the Gen5 Data Analysis software interface. The reduction of the DPPH radical was calculated as a percentage of inhibition by equation (6):

$D P P H$ inhibition $(\%)=\frac{(A c-A s)}{A c} \times(100)$

where $A c$ is the control absorbance and As is the absorbance of the sample.

\subsubsection{Total phenolic content}

The total phenolic content was estimated by colorimetric assay according to the methodology reported by Wong, Muñiz, Aguilar, Rodríguez, and Aguilar (2014). First, $20 \mu \mathrm{L}$ of film solution was mixed with $20 \mu \mathrm{L}$ of Folin-Ciocalteu reagent in a well. After, $5 \mathrm{~min}, 20 \mu \mathrm{L}$ of sodium carbonate $\left(0.01 \mathrm{~mol} \mathrm{~L}^{-1}\right)$ was added to each sample and allowed to stand for $5 \mathrm{~min}$. Then, $125 \mu \mathrm{L}$ of distilled water was added. Absorbance was read at $790 \mathrm{~nm}$ (Epoch, Biotek industries, Highland park, USA). Results were expressed as mg of gallic acid equivalents per $\mathrm{g}$ of film solution ( $\mathrm{mg} \mathrm{g}^{-1} \mathrm{GAE}$ ), according to a GA standard curve.

\subsubsection{Contact angle measurements}

The influence of addition of antioxidant extract on the surface polarity of films was studied by means of contact angle measurements. Briefly, one drop of $2 \mu \mathrm{L}$ of water was placed on the surface of the films and a Contact Angle System OCA15 Plus with CCD video camera (resolution of $752 \times 582$ pixels) and C20 software was used (Fabra et al., 2016).

\subsection{Evaluation of edible coating}

\subsubsection{Fruit conditioning and coating application}

Peaches (Prunus persica L. Batch cv. 'Red Heaven') were purchased at the commercial ripening stage from a local market in Braga, Portugal in April 2016. The fruits were selected in maturity ripe stage, with uniform weight $(88.53 \pm 5.14 \mathrm{~g})$ and with no physical damage. Fruits was immediately transported to the industry and processes laboratory. Subsequently, the fruit were washed and disinfected $\left(500 \mathrm{~g} \mathrm{~L}^{-1}\right.$ sodium hypochlorite) for $15 \mathrm{~min}$ followed by washing with distilled water and then surface dried at room temperature.

The coating application was conducted by immersing peaches in the following treatments: F, FE and distilled water (control) for $10 \mathrm{~min}$, then immediately dried under air flow $\left(25^{\circ} \mathrm{C}\right)$ until solidification (Approximately $15 \mathrm{~min}$ ) of edible coating (Guillén et al., 2013). Small portions of the outer surface $(1 \times 8 \mathrm{~cm})$ of the fruit were cut with a knife and placed on a glass plate in order to measure the contact angle.

\subsubsection{The wettability}

The wettability was studied by determining the values of the spreading coefficient $\left(W_{s}\right)$ and the works of adhesion $\left(W_{a}\right)$ and cohesion $\left(W_{c}\right)$. The contact angle $(\theta)$ of a liquid drop on a solid surface is defined by the mechanical equilibrium of the drop under the action of three interfacial tensions: solid-vapor $\left(\gamma_{S V}\right)$, solid-liquid $\left(\gamma_{S L}\right)$, and liquidvapor $\left(\gamma_{L V}\right)$. The equilibrium spreading coefficient $\left(W_{s}\right)$ is defined by equation (7) (Rulon \& Robert, 1993), and can only be negative or zero.

$W_{s}=W_{a}-W_{c}=\gamma_{S V}-\gamma_{L V}-\gamma_{S L}$

$W_{a}=\gamma_{L V}(1+\cos (\theta))$

$W_{c}=2 \gamma_{L V}$

$W_{s}$ was obtained by measuring the contact angle $(\theta)$ between the coating solutions and the peach surface and the surface tension $\left(\gamma_{L}\right)$ of the coating solutions. The contact angle at the peach surface was measured by the sessile drop method (Carneiro-da-Cunha et al., 2009). Briefly, one drop of $2 \mu \mathrm{L}$ was placed on the fruit surface and the contact angle was measured with Contact Angle System OCA15 Plus with CCD video camera (resolution of $752 \times 582$ pixels) and C20 software. Fifteen replicates of contact angle measurements and four replicates of surface tension measurements were obtained at $22^{\circ} \mathrm{C}$.

Surface tension values $\left(\gamma_{L}\right)$ of each coating solution were determined according to the Ring method described by Gudiña et al. A Krüss K6 tensiometer (Krüss $\mathrm{GmbH}$, Germany) equipped with a $1.9 \mathrm{~cm}$ De Noüy platinum ring was used. All the measurements were performed in triplicate at room temperature $\left(20^{\circ} \mathrm{C}\right)$.

\subsubsection{Zeta potential}

Zeta potential $(Z p)$ was determined by dynamic light scattering (DLS) with a Malvern Zetasizer, NANO ZS (Malvern Instruments Limited, UK), using a He-Ne laser (wavelength of $633 \mathrm{~nm}$ ) and a detector angle of $173^{\circ}$. The $Z p$ values were calculated using the Smoluchowski equation (Hunter, 1988).

\subsubsection{Gas transfer rate and ethylene production}

Two peaches were placed inside a hermetic jar by treatment. Temperature and relative humidity $(R H)$ were monitored with an iButton Hygrochron Temperature/Humidity Logger (DS1923, USA). 
The jar was stored in a controlled chamber (Binder KBF, Germany) at $20 \pm 1{ }^{\circ} \mathrm{C}$ and $\mathrm{RH}$ of $80 \pm 1 \%$. Respiration rate and ethylene production were measured every day during eight days, by extracting $500 \mathrm{~mL}$ of air inside of the jars with a syringe through a septum fitted in the jar lid (Lima et al., 2010).

2.5.4.1. $\mathrm{O}_{2}$ and $\mathrm{CO}_{2}$ transfer rates. The $\mathrm{O}_{2}$ and $\mathrm{CO}_{2}$ production/ consumption rates were determined using a gas chromatograph (GC Bruker Scion 456, USA) at $100^{\circ} \mathrm{C}$ with a column Packed SS MolSieve $13 \mathrm{x}(80 / 100), 2 \mathrm{~m} \times 2 \mathrm{~mm} \times 1 / 8^{\prime \prime}$ to separate the $\mathrm{O}_{2}$ and a column megabore BR Q PLOT, $30 \mathrm{~m} \times 0.53 \mathrm{~mm}, 0,20 \mu \mathrm{m}$ (film thickness) to separate the $\mathrm{CO}_{2}$ and Thermal Conductivity Detector (TCD) at $130{ }^{\circ} \mathrm{C}$. Argon at $30 \mathrm{~mL} \mathrm{~min}^{-1}$ and Helium at $15 \mathrm{~mL} \mathrm{~min}^{-1}$ were used as carrier gas. A mixture containing $10 \% \mathrm{CO}_{2}, 20 \% \mathrm{O}_{2}$ and $70 \% \mathrm{~N}_{2}$ was used as a standard for calibration. All determinations were performed at $20 \pm 1{ }^{\circ} \mathrm{C}$ for eight days. The $\mathrm{O}_{2}$ and $\mathrm{CO}_{2}$ rates were determined as established by Cerqueira et al. (2009), applying Equations (10) and (11), developed for a closed system impermeable to gases.

$R_{0_{2}}=-\left(\frac{d y_{O_{2}}}{d t}\right) \cdot\left(\frac{V_{f}}{w}\right)$

$R_{\mathrm{CO}_{2}}=\left(\frac{d y_{\mathrm{CO}_{2}}}{d t}\right) \cdot\left(\frac{V_{f}}{w}\right)$

where, $R_{\mathrm{O} 2}$ is the $\mathrm{O}_{2}$ consumption rate $\left(\mu \mathrm{g} \mathrm{kg}{ }^{-1} \mathrm{~s}^{-1}\right), R_{\mathrm{CO} 2}$ is the $\mathrm{CO}_{2}$ production rate, $\left(\mu \mathrm{gg}^{-1} \mathrm{~s}^{-1}\right), w(\mathrm{~g})$ is the weight of the peach, and $V_{f}$ (L) is the free volume of the container. The free volume $V_{f}$ of the package was calculated by equation (12):

$V_{f}=V_{p}-\frac{w}{\rho_{\text {peach }}}$

where, $V_{\rho}(\mathrm{L})$ is the total volume of the container, $w(\mathrm{~g})$ is the weight of the peach, and $\rho_{\text {peach }}$ is the true density of the peach fruit, in this case, $985 \mathrm{~g} \mathrm{~L}^{-1}$, obtained experimentally following the method described by Zohrabi, Seiiedlou, and Alipasandi (2013). The graph of $\mathrm{O}_{2}$ consumed versus time or $\mathrm{CO}_{2}$ produced versus time was used to calculate the slopes corresponding to the derivatives, $\mathrm{d} y \mathrm{O}_{2} / \mathrm{d} t$ (or $\mathrm{d} y \mathrm{CO}_{2} / \mathrm{d} t$ ).

2.5.4.2. Ethylene production. Ethylene production rates were monitored using a gas chromatograph (Varian 3800, USA) with a column megabore Zebron ZB Wa $\times$ Plus $30 \mathrm{~m} \times 0.53 \mathrm{~mm}, 1,00 \mu \mathrm{m}$ (Injector Split/splitless at $250{ }^{\circ} \mathrm{C}$ ), and flame ionization detector (FID) at $250{ }^{\circ} \mathrm{C}$, air at $250 \mathrm{~mL} \mathrm{~min}^{-1}, \mathrm{H}_{2}$ at $30 \mathrm{~mL} \mathrm{~min}^{-1}$ and makeup gas $\left(\mathrm{N}_{2}\right)$ at $30 \mathrm{~mL} \mathrm{~min}^{-1}$. Helium was used as a carrier gas at a flow rate of $4 \mathrm{~mL} \mathrm{~min}^{-1}\left(60^{\circ} \mathrm{C}\right)$. Ethylene (Calgaz, UK) was used as a standard. Ethylene rate was calculated similarly to $\mathrm{CO}_{2}$, applying Equation (13).

$R_{\text {Ethylene }}=\left(\frac{d y_{\text {Ethylene }}}{d t}\right) \cdot\left(\frac{V_{f}}{w}\right)$

where, $R_{\text {Ethylene }}$ is the ethylene production rate $\left(\mathrm{ng} \mathrm{kg}^{-1} \mathrm{~s}^{-1}\right), w(\mathrm{~g})$ is the weight of the peach, and $V_{f}(\mathrm{~L})$ is the free volume of the container. The graph of ethylene produced vs. time was used to calculate the slopes, which correspond to the derivative, dyEthylene/dt.

\subsection{Statistical analyses}

The experimental design was completely randomized. All data were expressed as mean values \pm SD. The Student's $t$-test was run to determine significant differences $(p<0.05)$ in the partial characterization of edible films. The other data were subjected to analysis of variance (ANOVA) $(p<0.05)$ and the mean comparisons were performed using the Tukey's test to examine if differences between treatments were significant $(\alpha=0.05)$. All statistical determinations were performed using Statistica 7.0 software (StatSoft, Tulsa OK, USA).
Table 1

Proximal chemical composition of mango peels variety Ataulfo.

\begin{tabular}{ll}
\hline Component & Concentration (\%) \\
\hline Moisture (fresh) & $64.06 \pm 0.023$ \\
Moisture (dry) & $5.57 \pm 0.153$ \\
Ash & $4.33 \pm 0.138$ \\
Protein & $5.05 \pm 0.014$ \\
Lipid & $1.78 \pm 0.212$ \\
Carbohydrates & $88.87 \pm 0.381$ \\
Total dietary fiber & $24.35 \pm 0.664$ \\
Soluble Dietary Fiber & $4.17 \pm 0.558$ \\
Insoluble fiber Dietetics & $20.18 \pm 0.770$ \\
Hemicellulose & $5.62 \pm 0.565$ \\
Cellulose & $8.16 \pm 0.176$ \\
Lignin & $6.41 \pm 0.417$ \\
\hline
\end{tabular}

Values reported are the means \pm standard deviations $(n=3)$.

Values are expressed on dry weight basis.

\section{Results and discussion}

\subsection{Chemical composition of MPF}

The total ash, protein, lipid and dietary fiber content in MPF are shown in Table 1 . The contents of ash and protein were higher than those previously reported by Rojas et al. (2015) $(2.12 \%$ and $3.04 \%$, respectively) in Ataulfo mango peel; contrarily, the lipid content was lower $(2.35 \%)$. On the other hand, the dietary fiber content was similar to that reported in Ataulfo mango peel (23.6\%) by García, García, Bello, Sáyago, and Oca (2013). The results of this study were similar to those presented by other authors in mango peels of other varieties (Ajila, Naidu, Bhat, \& Rao, 2007b, 2007a). The results evidenced the high content of biopolymers, mainly represented in dietary fiber (24.3\%). Previously Serna et al. (2016), reported that pectin is the major component of soluble dietary fiber in the mango peel, this polysaccharide is widely used as a food additive for its thickening, gelling and emulsifying properties (Rojas et al., 2015); therefore, naturally present pectin can favor the use of peel in the formulation of biodegradable films and coatings. As previously reported Andrade, Ferreira, and Gonzales (2014), an available content of carbohydrate higher than 84\%, including insoluble dietary fiber content of $80 \%$, is suitable to form biodegradable films. In addition to the reduction in costs, the complete use of the mango peel ensures the use of all the valuable components present in the polymer matrix, e.g. the proteins have beneficial effects in the increase of the mechanical properties, as the amino acids allow forming numerous linkages via disulfide (S-S) covalent bonding, electrostatic forces, hydrogen bonding and hydrophobic interactions (Flores-Lopez, Cerqueira, Jasso, \& Vicente, 2016). Meanwhile, lipids contribute significantly to reduce the WVP, and their incorporation in polysaccharide and protein films has the potential to improve the moisture barrier (Pérez-Gago \& Rhim, 2014).

\subsection{Evaluation of edible films}

WVP measures the diffusion of water molecules through the crosssection of the film and can give an estimation of its barrier properties (Acevedo-fani, Salvia-trujillo, Rojas-graü, \& Martín-belloso, 2015). In a food product, the transfer of moisture must be reduced to control the loss of moisture to the environment; for this reason, low values of WVP are ideal. The results for WVP of the films tested here are shown in Table 2. FE film presents WVP values significantly higher than those measured for F film. Similar behavior was observed by Bierhalz, da silva, and Kieckbusch (2012), in films formulated with pectin and added with an antimicrobial compound. The authors associated this behavior to a looser packing of the film macromolecules increasing the free volume of the polymeric structure, which enhances permeability. This behavior may be reflected in a significant increase in the values of 
Table 2

Partial characterization of edible films.

\begin{tabular}{|c|c|c|}
\hline & $\mathrm{F}$ & $\mathrm{FE}$ \\
\hline WVP $\left(\times 10^{-10} \mathrm{~g} \mathrm{~m}^{-1} \mathrm{~s}^{-1} \mathrm{~Pa}^{-1}\right)$ & $0.88 \pm 0.02^{\mathrm{a}}$ & $1.00 \pm 0.00^{\mathrm{b}}$ \\
\hline Thickness (mm) & $0.10 \pm 0.00^{\mathrm{a}}$ & $0.11 \pm 0.01^{\mathrm{b}}$ \\
\hline Moisture (\%) & $3.11 \pm 0.84^{\mathrm{a}}$ & $4.14 \pm 1.30^{\mathrm{a}}$ \\
\hline Solubility (\%) & $60.24 \pm 4.38^{\mathrm{a}}$ & $52.56 \pm 9.66^{\mathrm{a}}$ \\
\hline Light transmission rate $\left(\% . \mathrm{T}_{600}\right)$ & $26.11 \pm 2.36^{\mathrm{a}}$ & $25.20 \pm 2.32^{\mathrm{a}}$ \\
\hline Transparency $\left(\mathrm{A}_{600} \mathrm{~mm}^{-1}\right)$ & $5.83 \pm 0.61^{\mathrm{a}}$ & $5.54 \pm 0.47^{\mathrm{a}}$ \\
\hline $\mathrm{L}^{*}$ & $73.11 \pm 0.75^{\mathrm{a}}$ & $72.29 \pm 0.77^{\mathrm{a}}$ \\
\hline$a^{*}$ & $10.39 \pm 0.38^{\mathrm{a}}$ & $10.32 \pm 0.70^{\mathrm{a}}$ \\
\hline$b^{*}$ & $53.13 \pm 1.72^{\mathrm{a}}$ & $48.34 \pm 0.36^{\mathrm{b}}$ \\
\hline DPPH radical scavenging activity (\%) & $51.90 \pm 3.57^{b}$ & $63.55 \pm 3.62^{\mathrm{a}}$ \\
\hline Polyphenols ( $\mathrm{mg} \mathrm{g}^{-1} \mathrm{GAE}$ ) & $14.67 \pm 3.57^{b}$ & $44.42 \pm 4.82^{\mathrm{a}}$ \\
\hline Contact angle $\left({ }^{\circ}\right)$ & $72.20 \pm 1.68^{\mathrm{a}}$ & $68.20 \pm 0.90^{\mathrm{b}}$ \\
\hline
\end{tabular}

Values reported are the means \pm standard deviations. Statistics were analyzed using the program Student's t-test. Means with different lowercase letters are significantly different $(\mathrm{p}<0.05)$. The same letters within the row indicate no significant difference among different samples.

thickness of the formulations added with antioxidant extract (Table 2). However, the WVP of edible films is affected by various factors including the nature of film forming material, type of plasticizer, additive, and film preparation process (Cheng, Wang, \& Weng, 2015). The WVP values obtained $\left(0.88 \times 10^{-10}-1.00 \times 10^{-10} \mathrm{~g} \mathrm{~m}^{-1} \mathrm{~s}^{-1} \mathrm{~Pa}^{-1}\right)$ are lower and, consequently, better than those reported by de Moraes et al. (2016), for films obtained with agro-industrial waste $\left(1.5 \times 10^{-10}\right.$ $2.8 \times 10^{-10} \mathrm{~g} \mathrm{~m}^{-1} \mathrm{~s}^{-1} \mathrm{~Pa}^{-1}$ ), Pitak and Rakshit (2011) in films made with chitosan, glycerol and banana flour $\left(4.5 \times 10^{-10}\right.$ $4.8 \times 10^{-10} \mathrm{~g} \mathrm{~m}^{-1} \mathrm{~s}^{-1} \mathrm{~Pa}^{-1}$ ) and Belyamani et al. (2014) in films of caseinate $\left(1.4 \times 10^{-10}-1.8 \times 10^{-10} \mathrm{~g} \mathrm{~m}^{-1} \mathrm{~s}^{-1} \mathrm{~Pa}^{-1}\right)$.

Moisture content and water solubility of $\mathrm{F}$ and $\mathrm{FE}$ films are also shown in Table 2. Both parameters were not affected significantly by the addition of antioxidants. Similar behavior was also observed by Bittencourt, Fávaro, Sobral, and Carvalho (2014) in gelatin films formulated with turmeric ethanolic extract, and by Li et al. (2014) in films made with gelatin and added with antioxidant extracts. According to Wu et al. (2013), these solubility values are justified by the increase in the structural strength due to greater interaction between polyphenols and polysaccharides present in the matrix.

The optical properties are very important in the analysis of edible films and coatings, particularly if the film is to be used in a food sensitive to degradation by light (Falguera et al., 2011). As shown in Table 2, the light transmission (measured at $600 \mathrm{~nm}$ ) of the film with the addition of extract (FE) did not present a significant difference $(p>0.05)$ with respect to F film. Zhang and Han (2006) reported higher results of light transmission and transparency in starch films. This result indicates that the films are a good barrier to radiation in the light spectrum measured. Li et al. (2014) reported that the addition of phenolic compounds decreases the transmission of light (-OH contained in polyphenols compounds). The values obtained in this work can be explained by the content of carotenoids and anthocyanins present in the mango peel, which absorb light at these wavelengths. In the color analysis, it is evidenced that the addition of antioxidant does not affect significantly $(p>0.05)$ luminosity nor $a^{*}$ values. The high values obtained for $b^{*}$ reflect the presence of typical yellow coloration of the pigments present in the mango peel.

Active packaging is an attractive technique for extending produce shelf life (Ribeiro-Santos, Andrade, Melo, \& deSanches-Silva, 2017). Table 2 showed a significant increase $(p<0.05)$ in the antioxidant activity and the polyphenol content in FE films. Results suggested that the addition of $0.07 \mathrm{~g} \mathrm{~L}^{-1}$ extract potentiated a strongest antioxidant activity. Such effect is due to the phenolic compounds present in the solution; as Dorta, Lobo, and González (2012) demonstrated, polyphenol content is responsible for antioxidant activity in mango byproducts.
Contact angle with water measurements allows the prediction of how hydrophobic a surface is, being a higher contact angle $\left(\theta>70^{\circ}\right)$ an indicative of a hydrophobic surface (Belyamani et al., 2014). Results in Table 2 show that films with antioxidant extract had a higher hydrophobicity $(p<0.05)$. The values of contact angle are consistent with the previously reported by Abreu et al. (2015) in films based on native corn starch $\left(45.3-82.2^{\circ}\right)$, and were higher than the values reported by Belyamani et al. (2014) in films of sodium caseinate $\left(55^{\circ}\right)$. It is worth highlighting that biopolymers commonly used to produce films usually require expensive pre-treatments (extraction, purification, and separation) blending with other materials, genetic or chemical modification or combinations of the above approaches to improve their barrier, optical and rheological properties (Fai et al., 2016). The results of this study demonstrate the potential of MPF extraction with buffer solutions to produce films with features suitable for use in foods.

\subsection{Evaluation of edible coatings}

Peach (Prunus persica) is a highly perishable produce item that is classified as a climacteric fruit and has a short storability because it undergoes rapid ripening (Guillén et al., 2013). Thus, it was used as a climacteric fruit model to study the effect of mango peel-based edible coatings.

\subsubsection{Wettability}

$W_{s}$ is one of the most important properties when evaluating the capacity of a solution to coat a surface of interest; values close to zero are considered most suitable for coating of a surface (Carneiro-daCunha et al., 2009). The values of Ws are shown in Fig. 2, from 0 to $120 \mathrm{~s}$ after the coating was applied on the surface of peaches. It is clear that after $60 \mathrm{~s}$ of adding the coating, Ws values remained constant. The addition of antioxidant extracts increased coatings' wettability, without having a significant effect with respect to $\mathrm{F}$ film. The addition of antioxidant extract to the coating forming solution reduced significantly the surface tension of the liquid: the solution without extract $(\mathrm{F})$ showed a surface tension of $57.82 \pm 0.36 \mathrm{mN} \mathrm{m}^{-1}$, whilst with antioxidant (FE) surface tension was $52.06 \pm 0.47\left(\mathrm{mN} \mathrm{m}^{-1}\right)$. These values were lower than those calculated for water $\left(69.80 \pm 0.00 \mathrm{mN} \mathrm{m}^{-1}\right)$. The positive effect of reducing the surface tension contributes to reducing significantly the cohesive forces $\left(F=115.64 \pm 0.73 \mathrm{mN} \mathrm{m}^{-1}\right.$ and $\mathrm{FE}=104.12 \pm 0.93 \mathrm{mN} \mathrm{m}^{-1}$ ), thus improving the compatibility between the solution and the fruits' skin surface. This phenomenon may be attributed to the reorientation of polar groups in the surface layer, which increases the hydrophobicity of the solution (Wiacek, 2015). In this regard, Foschia, Peressini, Sensidoni, and Brennan (2013) explained that the hydroxyl groups of antioxidant compounds, such as gallic acid, improve the wettability of coatings. Previously, Torres et al. (2017a) demonstrated that phenolic compounds such as $1,2,3,4,6$ penta-O-galloyl- $\beta$-D-glucose (PGG) and its derivatives are the

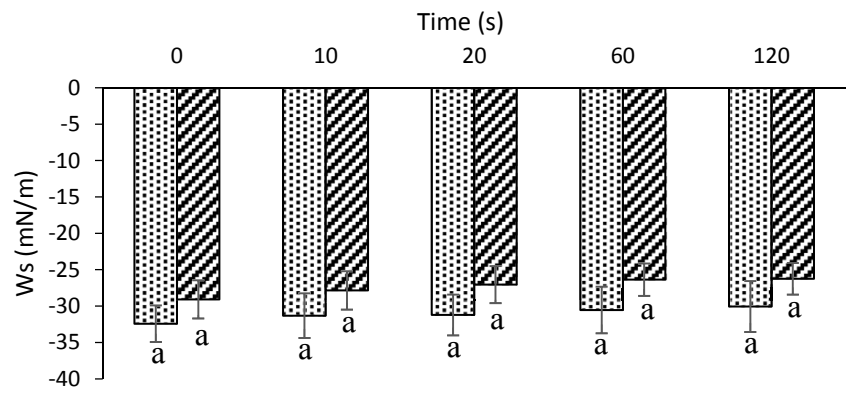

Fig. 2. Values of wettability determined for mango peel-based coatings ( $F$ ) and mango peel-based coatings with antioxidants of mango seed kernel (FE) vs time. Bars represent mean \pm standard error $(n=10)$. Identical letters indicate that the samples are not significantly different $(\mathrm{p}>0.05)$. 
predominant compounds in the extract of mango seed kernel. PGG is composed of five galloyl groups (carboxylic groups of gallic acids) with a glucose this structure-activity relationship especially the contributions of specific OH-groups gives its a high bioactivity (Torres et al., 2017b).

The charge of polysaccharides has a direct relationship with the zeta potential $(Z p)$ of the solution (Carneiro, Cerqueira, Souza, Teixeira, \& Vicente, 2011). $Z p$ expresses the surface charge of particles in a dispersion and for studying their stability from an electrostatic point of view, when $Z p$ values are further away from zero the corresponding solutions are more stable (Zambrano et al., 2013). Zp results reveal that $\mathrm{F}(-14.57 \pm 0.69 \mathrm{mV})$ and $\mathrm{FE}(-13.77 \pm 0.53 \mathrm{mV})$ solutions have a negative charge. This result shows that the solution formed with the mango peel has an anionic nature (Salvia, Rojas, Soliva, \& Martín, 2015). $Z p$ values of FE solution were higher than those reported in other edible coatings formulations ( -13.7 to $-2.1 \mathrm{mV}$ ) (Carneiro et al., 2011), and ensure the adequate stability of the solution. The good results obtained in this study open the possibility in future studies to optimize the parameters that influence the properties of biopackaging made with mango by-products.

\subsubsection{Ethylene production and respiration rate}

The coated peach allowed a lower gas exchange, and the coatings with antioxidant extract reduced significantly the production of $\mathrm{CO}_{2}$ (in $29 \%$ ) and $\mathrm{O}_{2}$ consumption (by 39\%) when compared with uncoated peaches (control) (Fig. 3). Although ethylene production is increased during storage, the fruits coated with mango peel and antioxidant extract showed a reduction greater than 64\%; a delay in ethylene production is related to the reduction of senescence of fruit (Shah, Vishwasrao, Singhal, \& Ananthanarayan, 2016). Reduction of ethylene production due to edible coatings application has been reported for peach (Guillén et al., 2013), fresh-cut apples coated with alginate (Guerreiro, Gago, Faleiro, Miguel, \& Antunes, 2017), tomato coated with gum arabic (Ali, Maqbool, Ramachandran, \& Alderson, 2010), and ciruelas recubiertas con alginate (Valero et al., 2013). This may be due to the creation of a modified atmosphere within the fruit created by the coatings (Ali et al., 2010; Elsabee \& Abdou, 2013; Falguera et al., 2011).

It is worth highlighting that the rate of $\mathrm{CO}_{2}$ production was higher than the rate of $\mathrm{O}_{2}$ consumption, both in coated and uncoated fruit. This guaranteed that the coating layer did not affect significantly the gas balance in the fruit and that only the transfer rates were decreased (Lima et al., 2010). Therefore, reducing maturation physiologically expressed in ethylene synthesis is associated with the effect of the coatings and not to the accumulation of $\mathrm{CO}_{2}$ in the package.

The synthesis of $\mathrm{CO}_{2}$ and $\mathrm{O}_{2}$ consumption in fruit presented a behavior similar to that observed in the production of ethylene. The addition of the antioxidant extracts significantly $(p<0.05)$ influenced the reduction of the respiratory rate and the production of ethylene compared to the control and the coating without extract. This behavior has already been reported by Guillén et al. (2013) in peaches coated with Aloe vera, material that has been reported to have a high antioxidant activity (Kang et al., 2014).

The difference between $\mathrm{F}$ and $\mathrm{FE}$ is the incorporation of a mango seed extract rich in phenolic compounds such as 1,2,3,4,6 penta-Ogalloyl- $\beta$-D-glucose (PGG) and its derivatives (Torres et al., 2017a). The beneficial effects of a coating with antioxidant extract in controlling respiratory rate can be explained by the increase of the wettability of the solution (Fig. 2). This factor ensures better coating of the skin of peaches and greater control in the transfer of gases. $\mathrm{CO}_{2}$ and $\mathrm{O}_{2}$ are critical factors for controlling postharvest behavior and quality of the fruit (Domínguez, Lafuente, Hernández, \& Gavara, 2016), thus, the coating with antioxidant extract has a great potential to increase the shelf life of peaches. Visual evaluation of peaches at eight days of storage $\left(20^{\circ} \mathrm{C}\right.$ and $\left.80 \% \mathrm{RH}\right)$ also confirmed the beneficial effect of the edible coating (Fig. 4) on the prolongation of shelf life, as the coated peaches did not present damage by microbial growth or by enzymatic browning.

\section{Conclusions}

This work shows the feasibility of using mango (Variety Ataulfo) byproducts in the formulation of edible films and coatings. Films of mango peel showed good properties of permeability, color, antioxidants and greater hydrophobicity. The addition of antioxidant extract of mango seed to the coatings formulation contributed to improve surface properties. A $39 \%$ less $\mathrm{O}_{2}$ consumption, $64 \%$ and $29 \%$ less ethylene and $\mathrm{CO}_{2}$ production respectively were observed in coated peach when compared with peaches without coating. This study demonstrate the great potential of mango by-products for producing coatings and packaging materials. It is important to continue research to optimize variables that influence the formulation of bio-packaging.

\section{Acknowledgments}

C. Torres-León thanks the Malta Council for Science and Technology (CONACYT) for his post-graduate scholarship (No. 340301). M. L. Flores-López thanks, CONACYT for the Ph.D. fellowship support (No. 215499/310847) and COECTY-Coahuila State Government (COAH2016-C11-A04). Authors are thankful to engineer Madalena Vieira and to Ph.D. Juan Carlos Contreras for their valuable suggestions during this study. a)

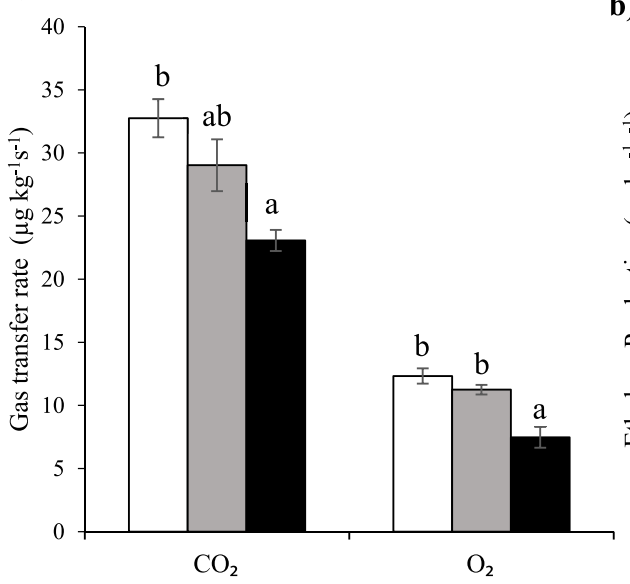

b)

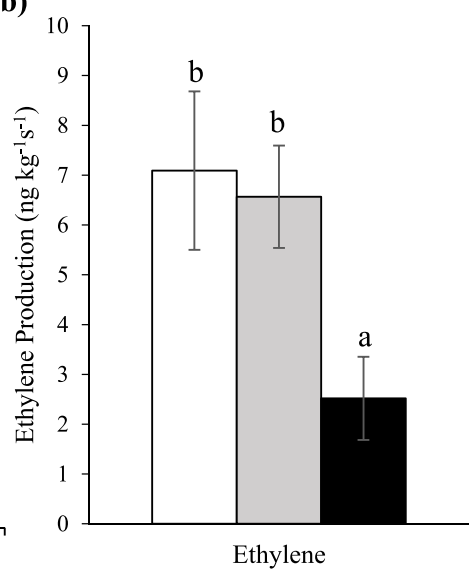

Fig. 3. $\mathrm{CO}_{2}$ and $\mathrm{O}_{2}$ transfer rates (a) and ethylene production rate (b) of peaches coated with mango peel (grey) or mango peel and antioxidant extract of mango seed (black) or distilled water as control (white) during storage ( 8 days) at $20^{\circ} \mathrm{C}$. Bars represent mean \pm standard error $(n=2)$. Different letters denote significant difference according to one-way ANOVA and Tukey's test ( $\mathrm{p}<0.05)$. 


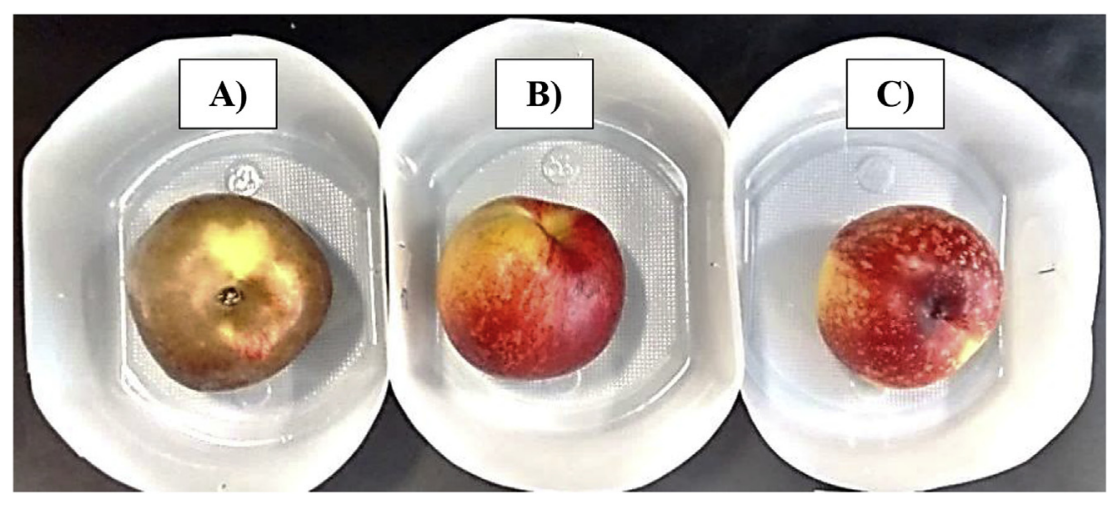

Fig. 4. Visual aspect of peaches on the eighth day of storage $\left(20^{\circ} \mathrm{C}, 80 \% \mathrm{RH}\right)$. (A) Uncoated peach samples (Control), (B) peel-based coated samples with antioxidants of seed kernel, (C) peel-based coated samples.

\section{References}

Abdalla, A., Darwish, S., Ayad, E., \& El-Hamahmy, R. (2007). Egyptian mango by-product 1. Compositional quality of mango seed kernel. Food Chemistry, 103, 1134-1140. https://doi.org/10.1016/j.foodchem.2006.10.017.

Abdullah, H., Mohammed, A., \& Abdullah, R. (2014). Cytotoxic effects of Mangifera indica L. kernel extract on human breast cancer (MCF-7 and MDA-MB-231 cell lines) and bioactive constituents in the crude extract. BMC Complementary and Alternative Medicine, 14, 199. https://doi.org/10.1186/1472-6882-14-199.

Abreu, A., Oliveira, M., de Sá, A., Rodrigues, R., Cerqueira, M., Vicente, A. A., et al. (2015). Antimicrobial nanostructured starch based films for packaging. Carbohydrate Polymers, 129, 127-134. https://doi.org/10.1016/j.carbpol.2015.04.021.

Acevedo-fani, A., Salvia-trujillo, L., Rojas-graü, M. A., \& Martín-belloso, O. (2015). Food Hydrocolloids Edible fi lms from essential-oil-loaded nanoemulsions:

Physicochemical characterization and antimicrobial properties. Food Hydrocolloids, 47, 168-177. https://doi.org/10.1016/j.foodhyd.2015.01.032.

Ajila, C., Bhat, S., \& Rao, P. (2007a). Valuable components of raw and ripe peels from two Indian mango varieties. Food Chemistry, 102, 1006-1011. https://doi.org/10.1016/j. foodchem.2006.06.036.

Ajila, C., Naidu, K., Bhat, S., \& Rao, U. (2007b). Bioactive compounds and antioxidant potential of mango peel extract. Food Chemistry, 105, 982-988. https://doi.org/10. 1016/j.foodchem.2007.04.052.

Ali, A., Maqbool, M., Ramachandran, S., \& Alderson, P. G. (2010). Gum Arabic as a novel edible coating for enhancing shelf-life and improving postharvest quality of tomato (Solanum lycopersicum L.) fruit. Postharvest Biology and Technology, 58, 42-47. https://doi.org/10.1016/j.postharvbio.2010.05.005.

Andrade, R., Ferreira, M., \& Gonzales, E. (2014). Functional capacity of flour obtained from residues of fruit and vegetables. International Food Research Journal, 21, $1675-1681$.

AOAC (1990). Official methods of analysis of the association of official analytical chemists (15 Ed.). Method 920.39. Arlington, Virginia, USA.

AOAC 991.43 (1993). Official methods of analysis of the Association of Oficial Analytical Chemists International. Methods of analysis for nutrion la beling chapter Method 991.43.Dietary fiber. (virginia) USA.

ASTM E96-92 (1990). Standard test methods for water vapor transmission of materials. Philadelphia, PA.

Ayala, J., Vega, V., Rosas, C., Palafox, H., Villa, J., Siddiqui, W., et al. (2011). Agroindustrial potential of exotic fruit byproducts as a source of food additives. Food Research International, 44, 1866-1874. https://doi.org/10.1016/j.foodres.2011.02. Research
021.

Azeredo, H., Rosa, M., Souza, F., \& Waldron, K. (2014). The use of biomass for packaging films and coatings. In Keith W. Waldron (Ed.). Advances in biorefineries (pp. 819-874). Cambrige, Uk: Elsevier Inc. https://doi.org/10.1533/9780857097385.2.819.

Belyamani, I., Prochazka, F., Assezat, G., \& Debeaufort, F. (2014). Mechanical and barrier properties of extruded film made from sodium and calcium caseinates. Food Packaging and Shelf Life, 2, 65-72. https://doi.org/10.1016/j.fpsl.2014.07.003.

Bierhalz, A., da silva, M., \& Kieckbusch, T. (2012). Natamycin release from alginate pectin films for food packaging applications. Journal of Food Engineering, 110, 18-25.

Bittencourt, C., Fávaro, C., Sobral, P., \& Carvalho, R. (2014). Gelatin-based films additivated with curcuma ethanol extract: Antioxidant activity and physical properties of films. Food Hydrocolloids, 40, 145-152.

Carneiro-da-Cunha, M. G., Cerqueira, M. A., Souza, B. W. S., Souza, M. P., Teixeira, J. A., \& Vicente, A. A. (2009). Physical properties of edible coatings and films made with a polysaccharide from Anacar-dium occidentale L. Journal of Food Engineering, 95(3), 379-385. https://doi.org/10.1016/j.jfoodeng.2009.05.020.

Carneiro, M., Cerqueira, M., Souza, B., Teixeira, J., \& Vicente, A. (2011). Influence of concentration, ionic strength and $\mathrm{pH}$ on zeta potential and mean hydrodynamic diameter of edible polysaccharide solutions envisaged for multinanolayered films production. Carbohydrate Polymers, 85, 522-528. https://doi.org/10.1016/j.carbpol. 2011.03.001.

Cazon, P., Velazquez, G., Ramírez, J., \& Vazquez, M. (2017). Food hydrocolloids polysaccharide-based fi lms and coatings for food packaging: A review. Food Hydrocolloids, 68, 136-148. https://doi.org/10.1016/j.foodhyd.2016.09.009.
Cerqueira, M., Bourbon, A., Pinheiro, A., Martins, J., Souza, B., Teixeira, J., et al. (2011). Galactomannans use in the development of edible films/coatings for food applications. Trends in Food Science \& Technology, 22, 662-671.

Cerqueira, M., Lima, Á., Teixeira, J., Moreira, R., \& Vicente, A. (2009). Suitability of novel galactomannans as edible coatings for tropical fruits. Journal of Food Engineering, 94, 372-378.

Cheng, S., Wang, B., \& Weng, Y. (2015). Antioxidant and antimicrobial edible zein/ chitosan composite films fabricated by incorporation of phenolic compounds and dicarboxylic acids. Lebensmittel-Wissenschaft und -Technologie- Food Science and Technology, 63, 115-121. https://doi.org/10.1016/j.lwt.2015.03.030.

Chiumarelli, M., \& Hubinger, M. D. (2014). Evaluation of edible films and coatings formulated with cassava starch, glycerol, carnauba wax and stearic acid. Food Hydrocolloids, 38, 20-27. https://doi.org/10.1016/j.foodhyd.2013.11.013.

Cuq, B., Gontard, N., Cuq, J., \& Guilber, S. (1996). Functional properties of myofibrillar protein based biopackaging as affected by film thickness. Journal of Food Science, 61, 580-584.

Domínguez, I., Lafuente, M., Hernández, P., \& Gavara, R. (2016). Influence of modified atmosphere and ethylene levels on quality attributes of fresh tomatoes (Lycopersicon esculentum Mill.). Food Chemistry, 209, 211-219. https://doi.org/10.1016/j. foodchem.2016.04.049.

Dorta, E., González, M., Lobo, M. G., Sánchez-Moreno, C., \& de Ancos, B. (2014) Screening of phenolic compounds in by-product extracts from mangoes (Mangifera indica L.) by HPLC-ESI-QTOF-MS and multivariate analysis for use as a food ingredient. Food Research International, 57, 51-60. https://doi.org/10.1016/j.foodres. 2014.01.012.

Dorta, E., Lobo, G., \& González, M. (2012). Using drying treatments to stabilise mango peel and seed: Effect on antioxidant activity. Food Science and Technology, 45, 261-268. https://doi.org/10.1016/j.lwt.2011.08.016.

Elsabee, M. Z., \& Abdou, E. S. (2013). Chitosan based edible films and coatings: A review. Materials Science \& Engineering. C, Materials for Biological Applications, 33, 1819-1841. https://doi.org/10.1016/j.msec.2013.01.010.

Espitia, P. J. P., Du, W.-X., Avena-Bustillos, R., de, J., Soares, N., de, F. F., et al. (2014). Edible films from pectin: Physical-mechanical and antimicrobial properties - a review. Food Hydrocolloids, 35, 287-296. https://doi.org/10.1016/j.foodhyd.2013.06. 005 .

Fabra, M., Flores, M. L., Cerqueira, M., Rodriguez, D., Lagaron, J., \& Vicente, A. (2016). Layer-by-Layer technique to developing functional nanolaminate films with antifungal activity. Food and Bioprocess Technology, 471-480. https://doi.org/10.1007/ s11947-015-1646-1.

Fai, A., Alves, M., de Barros, S., Vinhosa, N., Ferreira, M., \& de Andrade, E. (2016). Development and evaluation of biodegradable films and coatings obtained from fruit and vegetable residues applied to fresh-cut carrot (Daucus carota L.). Postharvest Biology and Technology, 112, 194-204. https://doi.org/10.1016/j.postharvbio.2015. 09.021.

Falguera, V., Quintero, J. P., Jiménez, A., Muñoz, J. A., \& Ibarz, A. (2011). Edible films and coatings: Structures, active functions and trends in their use. Trends in Food Science \& Technology, 22, 292-303. https://doi.org/10.1016/j.tifs.2011.02.004.

Flores-Lopez, M. L., Cerqueira, M. A., Jasso, D., \& Vicente, A. (2016). Perspectives on utilization of edible coatings and nano-laminate coatings for extension of postharvest storage of fruits and vegetables. Food Engineering Reviews, 8, 292-305. https://doi. org/10.1007/s12393-015-9135-x.

Foschia, M., Peressini, D., Sensidoni, A., \& Brennan, C. (2013). The effects of dietary fibre addition on the quality of common cereal products. Journal of Cereal Science, 58, 216-227. https://doi.org/10.1016/j.jcs.2013.05.010.

Galus, S., \& Kadzińska, J. (2015). Food applications of emulsion-based edible films and coatings. Trends in Food Science \& Technology, 45, 273-283. https://doi.org/10.1016/ j.tifs.2015.07.011.

García, M., García, H., Bello, L., Sáyago, S., \& Oca, M. (2013). Functional properties and dietary fiber characterization of mango processing by-products (Mangifera indica L., cv Ataulfo and Tommy Atkins). Plant Foods for Human Nutrition, 68, 254-258. https:// doi.org/10.1007/s11130-013-0364-y.

Guerreiro, A., Gago, C., Faleiro, M., Miguel, M., \& Antunes, M. (2015). The effect of alginate-based edible coatings enriched with essential oils constituents on Arbutus unedo L. fresh fruit storage. Postharvest Biology and Technology, 100, 226-233. 
https://doi.org/10.1016/j.postharvbio.2014.09.002.

Guerreiro, A. C., Gago, C. M. L., Faleiro, M. L., Miguel, M. G. C., \& Antunes, M. D. C. (2017). The effect of edible coatings on the nutritional quality of "Bravo de Esmolfe" fresh-cut apple through shelf-life. Lebensmittel-Wissenschaft und -Technologie- Food Science and Technology, 75, 210-219. https://doi.org/10.1016/j.lwt.2016.08.052.

Guillén, F., Díaz, H., Zapata, P., Valero, D., Serrano, M., Castillo, S., et al. (2013). Aloe arborescens and Aloe vera gels as coatings in delaying postharvest ripening in peach and plum fruit. Postharvest Biology and Technology, 83, 54-57. https://doi.org/10. 1016/j.postharvbio.2013.03.011.

Hunter, R. (1988). Zeta potential in colloid science, second pri. New York: Academic Press, Inc.

Kang, M., Kim, S., Kim, Y., Kim, E., Lee, S., Ko, S., et al. (2014). In vitro and in vivo antioxidant activities of polysaccharide purified from aloe vera (Aloe barbadensis) gel. Carbohydrate Polymers, 99, 365-371. https://doi.org/10.1016/j.carbpol.2013.07. 091.

Lima, Á., Cerqueira, M., Souza, B., Santos, E., Teixeira, J., Moreira, R., et al. (2010). New edible coatings composed of galactomannans and collagen blends to improve the postharvest quality of fruits - influence on fruits gas transfer rate. Journal of Food Engineering, 97, 101-109. https://doi.org/10.1016/j.jfoodeng.2009.09.021.

Li, J., Miao, J., Wu, J. L., Chen, S., \& Zhang, Q. (2014). Preparation and characterization of active gelatin-based films incorporated with natural antioxidants. Food Hydrocolloids, 37, 166-173. https://doi.org/10.1016/j.foodhyd.2013.10.015.

Molyneux, P. (2004). The use of the stable free radical diphenylpicryl-hydrazyl (DPPH) for estimating antioxidant activity. Songklanakarin Journal of Science and Technology, 26, 211-219.

de Moraes, T., Haas, T., de Oliveira, A., \& Hickmann, S. (2016). Valorization of food-grade industrial waste in the obtaining active biodegradable films for packaging. Industrial Crops and Products, 87, 218-228. https://doi.org/10.1016/j.indcrop.2016.04.039.

NOM-188-SCFI (2012). Mango Ataulfo del Soconusco, Chiapas (Mangifera caesia Jack ex Wall)Especificaciones y métodos de prueba.

Ochoa, E., Saucedo, S., Rojas, R., de la Garza, H., Charles, A., \& Aguilar, C. (2011). Evaluation of a candelilla wax-based edible coating to prolong the shelf-life quality and safety of apples. American Journal of Agricultural and Biological Sciences, 6, 92-98.

Pérez-Gago, M. B., \& Rhim, J.-W. (2014). Edible coating and film Materials: Lipid bilayers and lipid emulsions. In S. L. Taylor (Ed.). Innovations in food packaging (pp. 325-350). New York: Academic Press, Inc.

Pitak, N., \& Rakshit, S. (2011). Physical and antimicrobial properties of banana flour/ chitosan biodegradable and self sealing films used for preserving Fresh-cut vegetables. Lebensmittel-Wissenschaft und -Technologie- Food Science and Technology, 44, 2310-2315. https://doi.org/10.1016/j.lwt.2011.05.024.

Razavi, M., \& Zahedi, M. (2015). Characterisation of a new biodegradable edible film based on sage seed gum: Influence of plasticiser type and concentration. Food Hydrocolloids, 43, 290-298. https://doi.org/10.1016/j.foodhyd.2014.05.028.

Ribeiro-Santos, R., Andrade, M., Melo, N. R., \& de Sanches-Silva, A. (2017). Use of essential oils in active food packaging: Recent advances and future trends. Trends in Food Science \& Technology Journal, 61, 132-140. https://doi.org/10.1016/j.tifs.2016 11.021.

Ribeiro, S., \& Schieber, A. (2010). Bioactive compounds in mango (Mangifera indica L.). Bioactive Foods in Promoting Health, 34, 507-523. https://doi.org/10.1016/B978-012-374628-3.00034-7.

Rojas, R., Contreras, J., Orozco, M., Muñoz, C., Aguirre, J., \& Aguilar, C. (2015). Mango peel as source of antioxidants and Pectin: Microwave assisted extraction. Waste and Biomass Valorization. https://doi.org/10.1007/s12649-015-9401-4.

Rulon, J., \& Robert, H. (1993). Wetting of low-energy surfaces. In J. C. Berg (Ed.). Wettability. Marcel Dekker.

Salvia, L., Rojas, A., Soliva, R., \& Martín, O. (2015). Use of antimicrobial nanoemulsions as edible coatings: Impact on safety and quality attributes of fresh-cut fuji apples.
Postharvest Biology and Technology, 105, 8-16. https://doi.org/10.1016/j. postharvbio.2015.03.009.

Schieber, A., Stintzing, F., \& Carle, R. (2002). By-products of plant food processing as a source of functional compounds - recent developments. Trends in Food Science \& Technology, 12, 401-413.

Serna, L., García, E., \& Torres, C. (2016). Agro-industrial potential of the mango peel based on its nutritional and functional properties. Food Reviews International, 32, 364-376. https://doi.org/10.1080/87559129.2015.1094815.

Shah, N., Vishwasrao, C., Singhal, R., \& Ananthanarayan, L. (2016). N-Octenyl succinylation of pullulan: Effect on its physico-mechanical and thermal properties and application as an edible coating on fruits. Food Hydrocolloids, 55, 179-188. https://doi. org/10.1016/j.foodhyd.2015.11.026.

Taqui, L., \& Stamatin, L. (2014). Physical and barrier properties of apple pectin/cassava starch composite films incorporating Laurus nobilis L. Oil and Oleic Acid. Journal of Food Processing and Preservation, 38, 1982-1993. https://doi.org/10.1111/jfpp. 12174.

Torres, C., Rojas, R., Contreras, J., Serna, L., Belmares, R., \& Aguilar, C. (2016). Mango seed: Functional and nutritional properties. Trends in Food Science \& Technology, 55, 109-117. https://doi.org/10.1016/j.tifs.2016.06.009.

Torres, C., Rojas, R., Serna, L., Belmares, R., \& Aguilar, C. N. (2017a). Extraction of antioxidants from mango seed kernel: Optimization assisted by microwave. Food and Bioproducts Processing, 105, 188-196. https://doi.org/10.1016/j.fbp.2017.07.005.

Torres, C., Ventura, J., Serna, L., Ascacio, J., Contreras, J., \& Aguilar, C. (2017b). Pentagalloylglucose (PGG): A valuable phenoliccompound with functional properties. Journal of Functional Foods, 37, 176-189. https://doi.org/10.1016/j.jff.2017.07. 045.

Valero, D., Díaz-Mula, H. M., Zapata, P. J., Guillén, F., Martínez-Romero, D., Castillo, S., et al. (2013). Effects of alginate edible coating on preserving fruit quality in four plum cultivars during postharvest storage. Postharvest Biology and Technology, 77, 1-6. https://doi.org/10.1016/j.postharvbio.2012.10.011.

Van Soest, P., Robertson, J., \& Lewis, B. (1991). Methods for dietary fiber, neutral detergent fiber and nonstarch polysaccharides in relation to animal nutrition. Journal of Dairy Science, 74, 3583-3597.

Varzakas, T., Zakynthinos, G., \& Verpoort, F. (2016). Plant food residues as a source of nutraceuticals and functional foods. Foods, 5, 1-32. https://doi.org/10.3390/ foods5040088.

Wiacek, E. (2015). Effect of surface modification on starch biopolymer wettability. Food Hydrocolloids, 48, 228-237. https://doi.org/10.1016/j.foodhyd.2015.02.005.

Wong, J., Muñiz, D., Aguilar, P., Rodríguez, R., \& Aguilar, C. (2014). Microplate quantification of total phenolic content from plant extracts obtained by conventional and ultrasound methods. Phytochemical Analysis ; PCA, 25, 439-444. https://doi.org/10. 1002/pca. 2512.

Wu, J., Chen, S., Ge, S., Miao, J., Li, J., \& Zhang, Q. (2013). Preparation, properties and antioxidant activity of an active film from silver carp (Hypophthalmichthys molitrix) skin gelatin incorporated with green tea extract. Food Hydrocolloids, 32, 42-51. https://doi.org/10.1016/j.foodhyd.2012.11.029.

Zambrano, M., Mercado, E., Ramirez, P., Cornejo, M., Gutiérrez, E., \& Quintanar, D. (2013). Use of solid lipid nanoparticles (SLNs) in edible coatings to increase guava (Psidium guajava L.) shelf-life. Food Research International, 51, 946-953. https://doi. org/10.1016/j.foodres.2013.02.012.

Zhang, Y., \& Han, J. (2006). Plasticization of pea starch films with Monosaccharides and polyols. Journal of Food Science, 71, 253-261. https://doi.org/10.1111/j.1750-3841. 2006.00075.x.

Zohrabi, S., Seiiedlou, S., \& Alipasandi, A. (2013). Study some physical and mechanical properties of three cultivars of peach in maturation stages. World of Sciences Journal, 4, 108-117. 